\title{
Expression of vascular endothelial growth factor-b in human astrocytoma ${ }^{1}$
}

\author{
Jean Christophe Gollmer, Annie Ladoux, Jeanine Gioanni, Philippe Paquis, \\ Alain Dubreuil, Marcel Chatel, and Christian Frelin ${ }^{2}$ \\ Institut de Pharmacologie Moléculaire et Cellulaire, 06560 Valbonne, France [J.C.G., A.L., C.F.]; \\ Centre Antoine Lacassagne, Nice, France [J.G.]; Service de Neurochirurgie, Hôpital Pasteur, \\ 30 Avenue de la Voie Romaine, 06002 Nice Cedex, France [P.P.]; and Laboratoire de Neuro-Oncologie, \\ UER Médecine, 06102 Nice Cedex 2, France [A.D., M.C.]
}

Growth of human malignant gliomas is stringently dependent on an angiogenic process that probably involves vascular endothelial growth factor (VEGF). Expressions of mRNA coding for the different forms of VEGF were analyzed in surgical specimens from human astrocytomas. Low levels of placental growth factor (PGF) and VEGFC mRNA were observed in polymerase chain reaction, but not in Northern blot experiments. VEGF mRNA was found in some but not all grade and grade IV astrocytomas. VEGFB mRNA was observed in all tissue samples analyzed irrespective of the tumor grade. A new splice variant of VEGFB $\left(\right.$ VEGFB $\left._{155}\right)$ that lacks exons 5 and 6 is described. Expressions of VEGF mRNA in cultured glioblastomas cells were upregulated by hypoxia, but the sensitivity of the cells to hypoxia was reduced as compared with normal rat astrocytes. VEGF expression was depressed by dexamethasone. Expressions of VEGFB mRNA were affected neither by hypoxia nor by dexamethasone. The results indicate a coexpression of VEGF mRNA and VEGFB mRNA in human astrocytomas. Expression of VEGFB is markedly different from that of VEGF. Possible roles of VEGFB as a cofactor for

Received 12 July 1999, accepted 1 October 1999.

${ }^{1}$ This work was supported by the CNRS, ARC, Fondation de France, Ligue de Recherche Contre le Cancer, FEGEFLUC, Ministère de la Recherche (Equipe recommandée DRED), Programme Hospitalier de Recherche Clinique, and Centres d'application et Réseau Développement de Thérapies Géniques.

${ }^{2}$ Address correspondence and reprint requests to Christian Frelin, Institut de Pharmacologie Moléculaire et Cellulaire, CNRS UPR 411, 660 route des lucioles, 06560 Valbonne, France.

${ }^{3}$ Abbreviations used are as follows: GAPDH, glyceraldehyde-3phosphodeshydrogenase; MEM, modified Eagle's medium; PCR, polymerase chain reaction; PGF, placental growth factor; SDS, sodium dodecyl sulfate; VEGF, vascular endothelial growth factor. hypoxia-induced angiogenesis in human astrocytomas are discussed. Neuro-Oncology 2, 80-86, 2000 (Posted to Neuro-Oncology [serial online], Doc. 99-33, March 7, 2000. URL <neuro-oncology.mc.duke.edu>)

$\mathrm{V}$ $\mathrm{EGF}^{3}$ is a dimeric glycoprotein that acts as a selective mitogen for vascular endothelial cells and as a vascular permeability factor (Connoly et al., 1989; Leung et al., 1989). It binds to and induces biological responses via two tyrosine kinase receptors: Flt1 (DeVries et al., 1992) and Flk1/KDR (Terman et al., 1992). Vascular permeability activity and immunoreactive VEGF are found in brain cyst fluids (Berkman et al., 1993; Weindel et al., 1994). VEGF expression is upregulated in high-grade astrocytomas that are highly vascularized and edema associated and is specifically localized in tumor cells that are in the direct proximity of necrotic areas (Phillips et al., 1993; Plate et al., 1992; Shweiki et al., 1992). It has been proposed that local hypoxia adjacent to necrotic areas within tumors triggers VEGF expression and induces vascularization of these areas (Plate et al., 1992; Shweiki et al., 1992). This hypothesis is supported by the observation that hypoxia induces VEGF mRNA and protein expression in cultured tumoral or nontumoral cells (Goldberg and Schneider, 1994; Ladoux and Frelin, 1993; Shweiki et al., 1992).

Recent studies have identified four other members in the VEGF gene family: placental growth factor $(P G F)$ (Maglione et al., 1991, 1993), VEGFB (Olofsson et al., 1996a), VEGFC (Joukov et al., 1996), and VEGFD (Farnebo et al., 1999). The existence of multiple forms of VEGF that heterodimerize with VEGF and that recognize partially overlapping sets of receptors calls for a revaluation of the role of these factors in human astrocytoma. This study compares the expressions of mRNA for VEGF, PGF, VEGFB, and VEGFC in human brain astrocytomas and analyses the regulation of the expres- 
sion of VEGF and VEGFB in cultured human astrocytoma cells.

\section{Materials and Methods}

\section{Materials and Specimen Selection}

Chemicals were from Sigma Chemical Company (St. Louis, Mo.) unless otherwise indicated.

Brain tumor specimens obtained in patients who underwent surgery at Nice Hospital were retrospectively selected for analysis. Surgical specimens were immediately immersed in Dulbecco's MEM supplemented with 400 units $/ \mathrm{ml}$ penicillin and $200 \mu \mathrm{g} / \mathrm{ml}$ streptomycin and brought to the laboratory. They were then cut into three pieces under sterile conditions. One piece of tissue was immediately frozen in liquid nitrogen and used for RNA extraction. An adjacent piece was fixed in $15 \%$ formalin and used for histologic analysis. The third piece was used to isolate cells. Histologic typing was established according to current principles of neuropathology, and grading was based on the World Health Organization classification of brain tumors. All procedures were performed according to the rules of the Ethical Committee of the National Center for Scientific Research.

\section{Cell Cultures}

Cell suspensions were prepared from surgical specimens using a grinder sieve, were washed of contaminating blood and debris, and were seeded into $25-\mathrm{cm}^{2}$ culture flasks using Dulbecco's MEM supplemented with $2 \mathrm{mM}$ glutamine, $10 \%$ heat-inactivated fetal bovine serum (Roche Diagnostics, Meylan, France), $10 \mathrm{ng} / \mathrm{ml}$ epidermal growth factor, $5 \mathrm{mM}$ sodium pyruvate, 400 units $/ \mathrm{ml}$ penicillin, and $200 \mu \mathrm{g} / \mathrm{ml}$ streptomycin. Culture media were renewed twice a week. At confluence, cultures were dispersed using trypsin $(2 \mathrm{mg} / \mathrm{ml})$ in phosphate-buffered saline supplemented with $200 \mathrm{mg} / \mathrm{ml}$ EDTA. Suspended cells were seeded in the same culture medium at a split ratio of 2 and maintained in vitro for up to 40 passages. Rat C6 glioma cells (Chassande et al., 1988), rat brain capillary endothelial cells (Vigne et al., 1989), and cortical astrocytes from newborn rat cortex (Marsault et al., 1990) were prepared as previously described. The culture medium was Dulbecco's MEM supplemented with $10 \%$ fetal bovine serum, 100 units $/ \mathrm{ml}$ penicillin, and 100 $\mu \mathrm{g} / \mathrm{ml}$ streptomycin. Hypoxic conditions were generated as previously described (Eyssen-Hernandez et al., 1996). Briefly, the cells were washed with serum-free medium, incubated in Dulbecco's MEM supplemented with $1 \%$ fetal bovine serum for $24 \mathrm{~h}$ in a humidified atmosphere containing $5 \% \mathrm{CO}_{2}$, further incubated for $6 \mathrm{~h}$ in an airtight container (Institut Gustave Roussy, Villejuif, France), and continuously flushed with a mixture of gases containing $5 \% \mathrm{CO}_{2}$ and $95 \% \mathrm{~N}_{2}$.

\section{RNA Isolation and Northern Blots}

Tissue samples (10-60 mg) were minced with a sterile scalpel and homogenized with $1 \mathrm{ml}$ TRIzol Reagent (Life
Technologies, Cergy Pontoise, France) in a 2-ml Dounce homogenizer (Polylabo, Strasbourd, France). Extraction was then performed according to the manufacturer's instructions. RNA was extracted from cultured cells according to Chomczynski and Sacchi (1987).

RNA samples $(10 \mu \mathrm{g})$ were subjected to a denaturing electrophoresis on a $1.2 \%(\mathrm{wt} / \mathrm{vol})$ agarose gel and transferred to Nytran membranes (Schleicher and Schuell, Cera Labo, Ecquevilly, France). Blots were hybridized with VEGF, PGF, and GAPDH probes at $42^{\circ} \mathrm{C}$ in the presence of $30 \%$ formamide, $5 \times$ salinesodium phosphate EDTA, $5 \times$ Denhardt's, $0.1 \%$ SDS, and $100 \mu \mathrm{g} / \mathrm{ml}$ denatured salmon sperm DNA. Blots were hybridized with VEGFB and VEGFC probes at $47^{\circ} \mathrm{C}$ in the presence of $50 \%$ formamide, $5 \times$ salinesodium phosphate EDTA, $5 \times$ Denhardt's, 0.5\% SDS, and $100 \mu \mathrm{g} / \mathrm{ml}$ denatured salmon sperm DNA. After hybridization, blots were washed twice with $2 \times$ salinesodium phosphate EDTA containing $0.1 \%$ SDS at $42^{\circ} \mathrm{C}$ for $15 \mathrm{~min}$. Autoradiography was performed for 2 days with intensifying screens at $-80^{\circ} \mathrm{C}$ using Kodak X-Omat AR films. Quantification of the hybridization signals was performed using a Phosphorimager (Fuji Medical Systems, Stamford, Conn.). Signals were normalized to that of GAPDH.

The VEGF probe was a 605 -bp fragment corresponding to the whole VEGF $_{165}$ human coding sequence. The PGF probe was a 470-bp fragment (nucleotides 321-791, Genbank 354936). The VEGFB probe was a 678-bp fragment (nucleotides 1-678, Genbank U43368). The VEGFC probe was a 1481-bp fragment (nucleotides 352-1833, Genbank 394216). The GAPDH probe was kindly provided by Dr. F. Moreau-Gachelin. The $18 \mathrm{~S}$ ribosomic RNA probe was a 98-bp fragment corresponding to a conserved region in mammals (Raynal et al., 1984). Probes were labeled with ${ }^{32} \mathrm{P}$ using the multiprime DNA labeling system (Amersham, Les Ulys, France). Specific activities were $>5 \times 10^{8} \mathrm{cpm} / \mu \mathrm{g}$ DNA.

\section{PCR}

Reverse transcription was performed using 500 ng total RNA, $10 \mu \mathrm{g} / \mathrm{ml}$ oligo(dT)12-18, 200 units/assay Moloney leukemia virus reverse transcriptase (Life Technologies), and deoxyribonucleoside triphosphates $(0.5$ $\mathrm{mM}$ each). Reaction was carried out for $1 \mathrm{~h}$ at $37^{\circ} \mathrm{C}$.

PCR was performed using $1 / 10$ of the reverse transcription volume, $400 \mu \mathrm{M}$ deoxyribonucleoside triphosphates, primers (4 ng/ $\mu$ l, Genset, Paris, France), and 20 units/ml Goldstar DNA polymerase (Eurogentec, Seraing, Belgium) in a final volume of $25 \mu$ l. Primers, annealing temperatures, and product lengths are listed in Table 1. After heating the samples for $1 \mathrm{~min}$ at $95^{\circ} \mathrm{C}, 30$ cycles of amplification $\left(1 \mathrm{~min}\right.$ heating at $95^{\circ} \mathrm{C}, 1 \mathrm{~min}$ annealing, and 1.30 min elongation at $72^{\circ} \mathrm{C}$ ) were performed. Samples were then left at $72^{\circ} \mathrm{C}$ for $10 \mathrm{~min}$. PCR products were subcloned into the insert site of pTAg vector (kit LigATor; R\&D Systems, Abingdon, U.K.) and sequenced using the Taq dye deoxy terminator sequencing system (kit Prism; Perkin Elmer, Les Ulys, France) and an Applied Biosystems (Les Ulys, France) 373A DNA Sequencer. 
Table 1. Primers and annealing temperatures used in PCR experiments

\begin{tabular}{|c|c|c|c|}
\hline & Primers & Annealing temperature & Product size $(b p)$ \\
\hline \multirow[t]{3}{*}{$\overline{\text { VEGF }}$} & Sense (5'-CCATGAACTTTCTGCTSTCTTG-3') & $52^{\circ} \mathrm{C}$ & $704\left(\right.$ VEGF $\left._{189}\right)$ \\
\hline & Antisense (5'-GGTGAGAGRTCTRGTTCCCGA-3') & & $632\left(\mathrm{VEGF}_{165}\right)$ \\
\hline & & & $500\left(\right.$ VEGF $\left._{121}\right)$ \\
\hline \multirow[t]{2}{*}{ PGF } & Sense (5'-GATGCCGGTCATGAGGCTGT-3') & $59^{\circ} \mathrm{C}$ & $470\left(\mathrm{PGF}_{149}\right)$ \\
\hline & Antisense (5'-CTCTCCTCCAAGGGGTGGGT-3') & & $533\left(\mathrm{PGF}_{170}\right)$ \\
\hline \multirow[t]{3}{*}{ VEGFB } & Sense (5'-CCATGAGCCCTCTGCTCCGCC-3') & $60^{\circ} \mathrm{C}$ & $678\left(\right.$ VEGFB $\left._{186}\right)$ \\
\hline & Antisense (5'-GCCATGTGTCACCTTCGCAGC-3') & & $577\left(\right.$ VEGFB $\left._{167}\right)$ \\
\hline & & & $541\left(\mathrm{VEGFB}_{155}\right)$ \\
\hline \multirow[t]{2}{*}{ VEGFC } & Sense (5'-ATGCACTTGCTGGGCTTCTTC-3') & $57^{\circ} \mathrm{C}$ & 1481 \\
\hline & Antisense (5'-TCTTGGCTGTTTGGTCATTGG-3') & & \\
\hline
\end{tabular}

Abbreviations: PCR, polymerase chain reaction; VEGF, vascular endothelial growth factor; PGF, placental growth factor.

\section{Southern Blots}

PCR products were loaded onto a $1 \%$ agarose gel column containing ethidium bromide and transferred onto Nytran N Plus membranes (Schleicher and Schuell). Hybridization was carried out with the appropriate probe as described in the section on Northern blots.

\section{Results}

\section{Expression of VEGF Genes in Brain Tumors}

We analyzed 37 brain tissue samples. They comprised 1 normal tissue (hippocampal cortex from cortectomy for temporal lobe epilepsy), 3 meningiomas, 8 grade II astrocytomas, 8 grade III astrocytomas, and 17 glioblastomas. Expression of VEGF, VEGFB, VEGFC, and PGF was analyzed using Northern blot experiments. Data obtained are summarized in Table 2.

VEGF mRNA was mainly observed in grade III and IV astrocytomas (Fig. 1). The major forms found were $\mathrm{VEGF}_{121}$ and $\mathrm{VEGF}_{165}$ (Fig. 2). We observed, however, that transcripts coding for $\mathrm{VEGF}_{121}$ and $\mathrm{VEGF}_{165}$, which were negative in Northern blot experiments, were detected in grade II astrocytomas. Very low levels of expression were found in the normal brain tissue and in grade I astrocytomas.

Differences in hybridization signals were not due to loading errors as evidenced by $18 \mathrm{~S}$ ribosomal RNA signals. These results, although nonquantitative, suggest

Table 2. Expressions of mRNA for VEGF, VEGFB, VEGFC, and PGF in tumor tissue samples

\begin{tabular}{lcccc} 
Tissue & VEGF & VEGFB & VEGFC & PGF \\
\hline Normal & $0 / 1$ & $1 / 1$ & $0 / 1$ & $0 / 1$ \\
I & $0 / 3$ & $3 / 3$ & $0 / 3$ & $0 / 3$ \\
II & $1 / 6$ & $6 / 7$ & $0 / 7$ & $0 / 3$ \\
III & $3 / 8$ & $6 / 6$ & $0 / 6$ & $0 / 7$ \\
IV & $10 / 17$ & $15 / 16$ & $0 / 16$ & $0 / 9$ \\
\hline
\end{tabular}

This summary considers the results of only Northern blots and excludes PCR data that were positive for VEGFC and PGF.

Abbreviations: See Table 1. that VEGF mRNA is expressed in all brain tissues examined and is upregulated in high-grade astrocytomas.

Messenger RNA for VEGFB (1.4 kb) was detected in almost all samples analyzed, including low-grade astrocytomas and one sample of normal brain tissue (Table 2). Fig. 3 shows a representative Northern blot. PCR experiments (Fig. 4) further indicated the presence of two transcripts coding for $\mathrm{VEGFB}_{186}$ and $\mathrm{VEGFB}_{167}$ in representative tissue samples.

Sequences corresponding to $\mathrm{PGF}_{149}, \mathrm{PGF}_{170}$, and VEGFC were amplified by PCR in all tissue samples analyzed (data not shown). The corresponding mRNA was not detected in Northern blots experiments.

Taken together, these results indicate that all forms of VEGF mRNA can be detected in human astrocytomas by PCR. Only VEGF $m$ RNA and VEGFB mRNA are detected in Northern blot experiments. Expression of VEGFB mRNA is ubiquitous. Expression of VEGF mRNA is markedly increased in grade III and IV astrocytomas.

\section{Identification of a New Splicing Variant of VEGFB}

PCR amplification products have been systematically sequenced to look for possible mutations. All sequences corresponded to the published sequences. A novel form of VEGFB was identified, however, in cultured cells isolated from a glioblastoma. The 155 amino acid sequence is shown in Fig. 5. It corresponded to a form of VEGFB

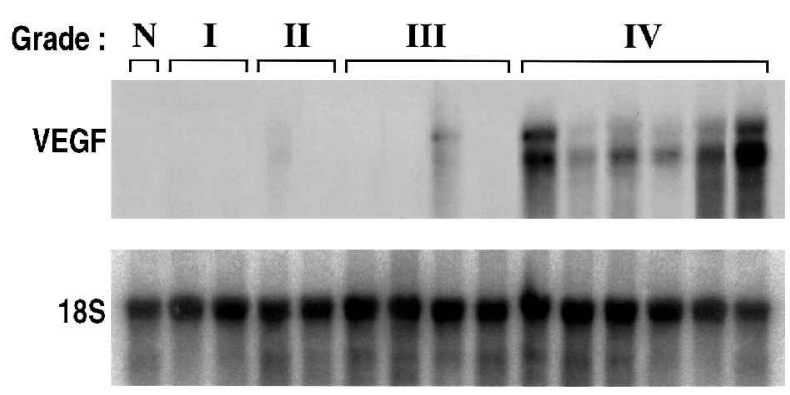

Fig. 1. Expression of VEGF in human astrocytomas. Representative Northern blots of total RNA were obtained from different brain tissue samples. Grades of the tumor samples are indicated on the top of the lanes. N, normal tissue; VEGF, vascular endothelial growth factor. 


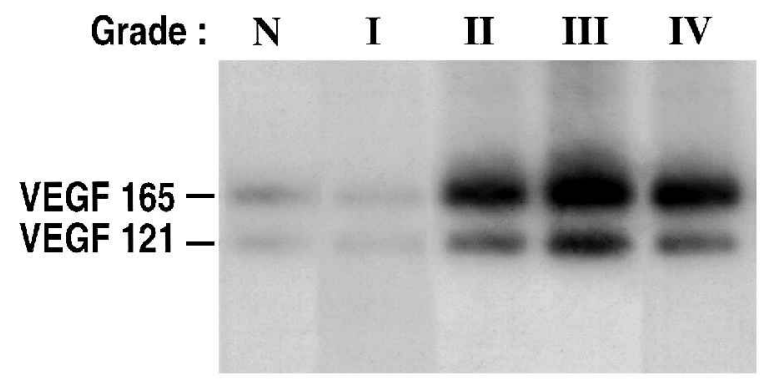

Fig. 2. Expression of VEGF splice variants in human astrocytomas. Representative Southern blots show expressions of $\mathrm{VEGF}_{121}$ and $V_{E G F}{ }_{165}$. Grades of the tumor samples are indicated on the top of the lanes. See Fig. 1 for abbreviations.

that lacks exons 5 and 6. Splicing introduced a frameshift and the use of a different open reading frame. As a consequence, the C-terminal sequences of $\mathrm{VEGFB}_{155}$ and VEGFB $_{186}$ are widely divergent. Splicing of exon 6 , which generates $\mathrm{VEGFB}_{167}$, induced a similar frameshift. As a consequence, C-terminal sequences of $\mathrm{VEGFB}_{167}$ and VEGFB $_{155}$ are identical.

\section{Effects of Hypoxia and Dexamethasone on VEGF and VEGFB Expressions by Cultured Human Astrocytoma Cells}

Cells were isolated from surgical specimens corresponding to different grades and grown in vitro. Expressions of VEGF mRNA were analyzed using Northern blot experiments. Expressions of VEGF mRNA appeared more ubiquitous in cultures than in tissue samples. It was not observed in two cell cultures isolated from grade I tumors. It was observed in 1 isolate out of 3 from grade II tumors, in 3 isolates out of 4 grade III tumors, and in 5 isolates out of 8 glioblastomas (data not shown).

Expression of VEGFB mRNA was detected in all cells analyzed. VEGFC mRNA was observed in cultured cells derived from grade III (2/2) and grade IV (1/3) astrocytomas. PGF mRNA was detected only in PCR experiments.

Fig. 6 compares expressions of VEGF mRNA and VEGFB mRNA in normoxic and hypoxic cultures of glioblastoma cells, of rat C6 astrocytoma cells, of normal rat astrocytes, and of rat brain capillary endothelial cells. Hypoxia induced VEGF mRNA expression in all cell types analyzed, but to variable extents. Human glioma cells, C6 glioma cells, and endothelial cells were the least sensitive. Normal rat astrocytes were two times more sensitive to hypoxia. These indicated that the sensitivity of glioma cells to hypoxia is not greater than that of untransformed cells. VEGFB mRNA expression was insensitive to hypoxia (Fig. 6).

Fig. 7 shows that dexamethasone $(1 \mu \mathrm{M})$ decreased VEGF mRNA expression by $40 \%$ to $70 \%$ in glioblastoma cells. It had no action on VEGFB mRNA expression. Thus, dexamethasone selectively reduced VEGF mRNA expression.

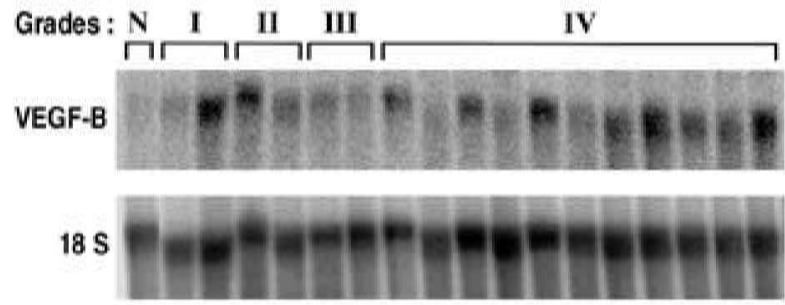

Fig. 3. Expression of VEGFB in human astrocytomas. Representative Northern blots of total RNA were obtained from different brain tissue samples. Grades of the tumor samples are indicated on the top of the lanes. See Fig. 1 for abbreviations.

\section{Discussion}

Previous studies have documented expression of VEGF (Chan et al., 1998; Machein et al., 1999; Schmidt et al., 1999) and PGF in human primary brain tumors (Nomura et al., 1998). This study confirmed the presence of low amounts of PGF in human astrocytomas by PCR experiments, but not by Northern blot experiments. VEGF mRNA was detected using PCR in all samples analyzed, but a hybridization signal could only be obtained with grade III and IV astrocytomas using Northern blot experiments. Thus, our results confirmed increased VEGF mRNA expression during the anaplastic progression of human astrocytomas.

VEGFB is widely expressed in rat tissues and is most prominent in heart and skeletal muscle (Olofsson et al., 1996a). Expression of VEGFB mRNA has previously been documented in normal mouse brains (Lagercrantz et al., 1998). It was also reported in human tumors of noncerebral origin (Salven et al., 1998). It has not yet been reported in normal human brain tissues. This study documents a prominent expression of VEGFB mRNA in all brain tissue samples analyzed: normal brain tissue, low-grade astrocytomas, and high-grade astrocytomas. Two forms of VEGFB have previously been described: VEGFB $_{186}$, which is encoded by unspliced transcripts, and $\mathrm{VEGFB}_{167}$, which lacks exon 6 and differs from VEGFB $_{186}$ in its C-terminal sequence due to a frameshift and a different open reading frame and stop codon (Olofsson et al., 1996b). These two forms are present in the tissue samples analyzed. This work further identifies a

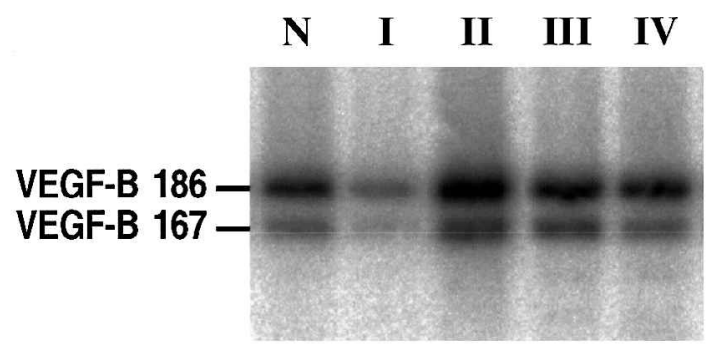

Fig. 4. Expression of VEGFB splice variants in human astrocytomas. Representative Southern blots show expressions of $\mathrm{VEGF}_{167}$ and $V_{E G F}{ }_{186}$. Grades of the tumor samples are indicated on the top of the lanes. See Fig. 1 for abbreviations. 


\section{A}

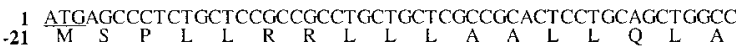

52 CCCGCCCAGGCCCCTGTCTCCCAGCCTGATGCCCCTGGCCACCAGAGGAAA

103 GTGGTGTCATGGATAGATGTGTATACTCGCGCT ACCTGCCAGCCCCGGGAG $14 \mathrm{~V} V \mathrm{~S}$ W I D V Y T R A T C Q P R E 154 GTGGTGGTGCCCT TGACTGTGGAGCTCATGGGCACCGTGGCCAAACAGCTG 205 GTGCCCAGCTGCGTGACTGTGCAGCGCTGTGGT GGCTGCTGCCCTGACGAT $48 \vee V \quad P \quad S \quad C \quad V \quad T \quad V \quad Q \quad R \quad C \quad G \quad G \quad C \quad C \quad P \quad D \quad D$

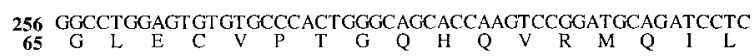

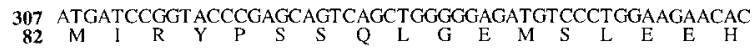

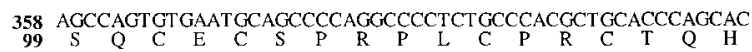

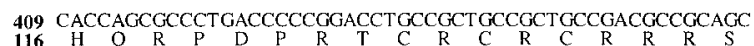
460 TTCCTCCGTTGCCAAGGGCGGGGCTTAGAGCTCAACCCAGACACCTGCAGG

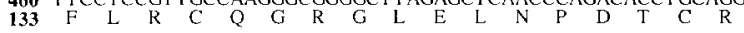
$\mathbf{5 1 1}$
$\mathbf{1 5 0}$
$\mathrm{C}$

B

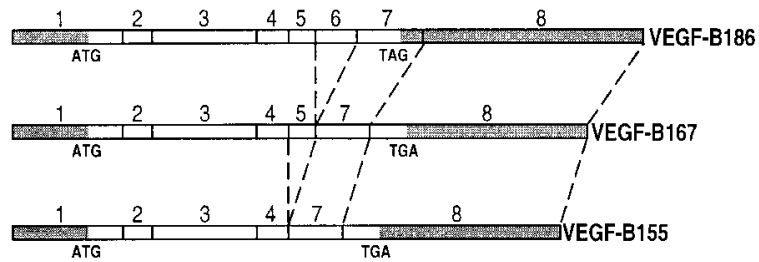

Fig. 5. Structure of $\mathrm{VEGFB}_{155}$. A. Nucleotide sequence and predicted amino acid sequence of $V_{E G F B}$. B. Compared structures of $\mathrm{VEGFB}_{186}, \mathrm{VEGFB}_{16}$, and VEGFB ${ }_{155}$. Splicing of exons 5 or 6 introduces a 1-base frameshift and a different reading frame. The stop codons of $\mathrm{VEGFB}_{167}$ and $\mathrm{VEGFB}_{155}$ are located 41 bases downstream of the stop codon of $\mathrm{VEGFB}_{186}$.

novel form of VEGFB consisting of 155 amino acids. It lacks exons 5 and 6 and has the same C-terminal sequence as $\mathrm{VEGFB}_{167}$ because splicing of exons 5 or 6 produces the same one-base frameshift. This form of VEGF is, however, a minor species and was detected only once.

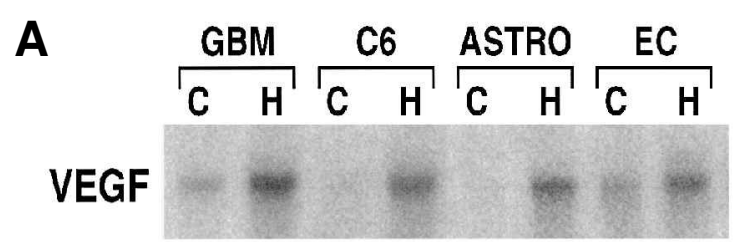

\section{VEGF-B}

\section{GAPDH}

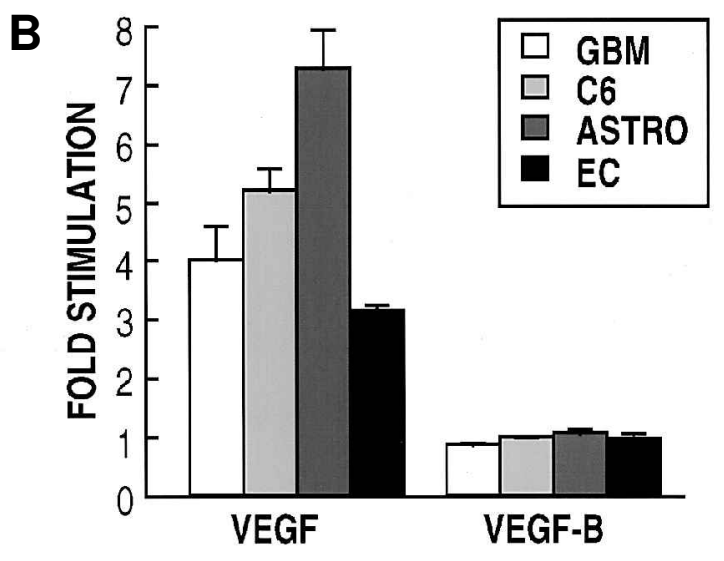

Fig. 6. Regulation of VEGF mRNA and VEGFB mRNA by hypoxia. A. Human glioblastoma cells, rat C6 glioma cells, normal rat astrocytes, and rat brain capillary endothelial cells exposed for $6 \mathrm{~h}$ to either normoxic or hypoxic conditions. RNA was prepared and Northern blots were probed with VEGF, VEGFB, and GAPDH probes as indicated. B. Normalized VEGF/GAPDH signals in hypoxic cultures expressed relative to those observed in control cultures maintained under normoxic conditions. Means \pm SEM $(n=3)$ are indicated. GBM, glioblastoma multiforme; ASTRO, astrocytes; EC, endothelial cells; C, control (normoxic) conditions; $\mathrm{H}$, hypoxic conditions; GAPDH, glyceraldehyde-3phosphate dehydrogenase.
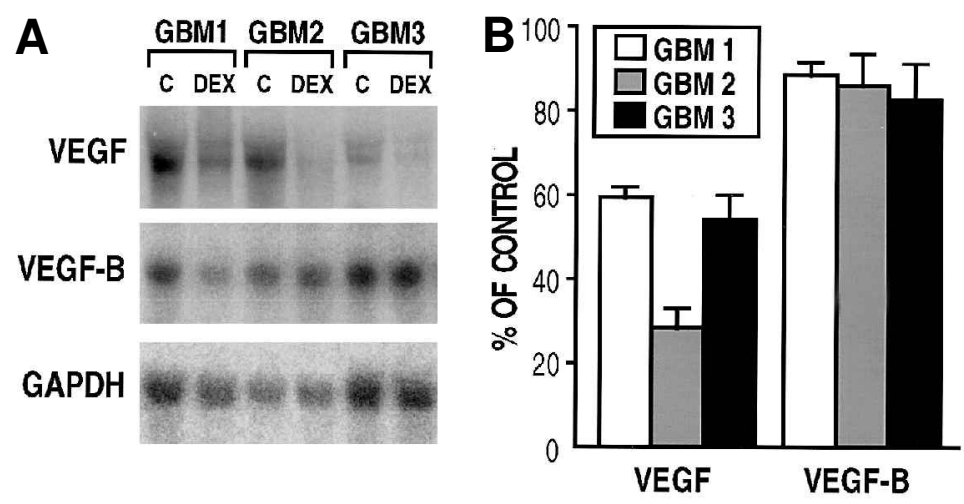

Fig. 7. Regulation of VEGF mRNA and VEGFB mRNA by dexamethasone. A. Northern blots showing the action of dexamethasone on VEGF and VEGFB expressions in cultured cells from three glioblastomas. Cells were incubated for $24 \mathrm{~h}$ in complete culture medium in the absence or presence of $1 \mu \mathrm{M}$ dexamethasone. RNA was isolated. Northern blots were probed with VEGF, VEGFB, and GAPDH probes as indicated. B. Normalized signals in dexamethasone-treated cultures expressed relative to those observed in control cultures. Means $\pm \operatorname{SEM}(n=3)$ are indicated. Dex, dexamethasone; C, cultured cells. See Fig. 6 for abbreviations. 
The astrocytoma cells isolated from tumors and maintained in culture expressed VEGF mRNA and VEGFB mRNA. VEGF mRNA expression was enhanced by hypoxia, but the sensitivity of human and rat glioma cells to hypoxia was not greater than that of normal astrocytes. Thus, glioma cells were not sensitized to the lack of oxygen. VEGF expression has been reported to be inhibited by dexamethasone (Finkenzeller et al., 1995; Nauck et al., 1998). In this study, dexamethasone partially reduced VEGF mRNA expression by glioma cells. Clinically, glucocorticoids are used to reduce brain tumor-associated cerebral edema. Because VEGF is a vascular permeability factor (Leung et al., 1989), it can be surmised that a reduction of VEGF expression by glioblastoma cells can contribute to therapeutic action of glucocorticoids. Expression of VEGFB mRNA in glioblastoma cells grown in vitro is affected neither by hypoxia nor by dexamethasone. The lack of action of hypoxia may be due to the fact that the promoter of the VEGFB gene lacks hypoxia-sensitive elements found in the promoter of the VEGF gene (Silins et al., 1997).

In conclusion, this study shows a surprising ubiquitous expression of VEGFB mRNA in human astrocytomas. Although this expression is not upregulated in high-grade astrocytomas and is insensitive to both hypoxia and glucocorticoids, the hypothesis that VEGFB contributes to the pathogenesis of astrocytomas cannot be excluded. VEGFB homodimers only recognize the VEGF receptor-1 (Flt1) (Olofsson et al., 1998). This receptor does not couple to the mitogen-activated protein /kinase cascade and does not promote mitogenic actions. It probably plays a role in the degradation of the extracellular matrix, in cell migration, and in controlling vascular permeability (Seetharam et al., 1995). Heterodimers formed of VEGFB and VEGF are, however, mitogenic for endothelial cells, possibly by activating VEGF receptor-2 (Flk1/KDR) (Olofsson et al., 1998). The binding of VEGFB to Flt1 may also enable VEGF binding to VEGF receptor-2 (Flk1/KDR), and may thus promote mitogenic actions of VEGF.

\section{References}

Berkman, R.A., Merrill, M.J., Reinhold, W.C., Monacci, W.T., Saxena, A., Clark, W.C., Robertson, J.T., Ali, I.U., and Oldfield, E.H. (1993) Expression of the vascular permeability factor/vascular endothelial growth factor gene in central nervous system neoplasms. J. Clin. Invest. 91, 153-159.

Chan, A.S., Leung, S.Y., Wong, M.P., Yuen, S.T., Cheung, N., Fan, Y.W., and Chung, L.P. (1998) Expression of vascular endothelial growth factor and its receptors in the anaplastic progression of astrocytoma, oligodendroglioma and ependymoma. Am. J. Surg. Pathol. 22, 816-826.

Chassande, O., Frelin, C., Farahifar, D., Jean, T., and Lazdunski, M. (1988) The $\mathrm{Na}^{+} / \mathrm{K}^{+} / \mathrm{Cl}^{-}$cotransport in $\mathrm{C} 6$ glioma cells: Properties and role in volume regulation. Eur. J. Biochem. 171, 425-433.

Chomczynski, P., and Sacchi, N. (1987) Single step method of RNA isolation by acid guanidinium thiocyanate-phenol-chloroform extraction. Anal. Biochem. 162, 156-159.

Connoly, D.T., Heuvelman, D.M., Nelson, R., Olander, J.V., Eppley, B.L., Delfino, J.J., Siegel, N.R., Leimgruber, R.M., and Feder, J. (1989) Tumor vascular permeability factor stimulates endothelial cell growth and angiogenesis. J. Clin. Invest. 84, 1470-1478.

de Vries, C., Escobedo, J.A., Ueno, H., Houck, K., Ferrara, N., and Williams, L.T. (1992) The fms-like tyrosine kinase, a receptor for vascular endothelial growth factor. Science 255, 989-991.

Eyssen-Hernandez, R., Ladoux, A., and Frelin, C. (1996) Differential regulation of cardiac heme oxygenase-1 and vascular endothelial growth factor mRNA expressions by hemin, heavy metals, heat shock and anoxia. FEBS Lett. 382, 229-233.

Farnebo, F., Piehl, F., and Lagercrantz, J. (1999) Restricted expression pattern of vegf-d in the adult and fetal mouse: High expression in the embryonic lung. Biochem. Biophys. Res. Commun. 257, 891-894.

Finkenzeller, G., Technau, A., and Marmé, D. (1995) Hypoxia-induced transcription of the vascular endothelial growth factor gene is independent of functional AP-1 transcription factor. Biochem. Biophys. Res. Commun. 208, 432-439.

Goldberg, M.A., and Schneider, T.J. (1994) Similarities between the oxygensensing mechanisms regulating the expression of vascular endothelial growth factor and erythropoietin. J. Biol. Chem. 269, 4355-4359.
Joukov, V., Pajusola, K., Kaipainen, A., Chilov, D., Lahtinen, I., Kukk, E., Saksela, O., Kalkkinen, N., and Alitalo, K. (1996) A novel vascular endothelial growth factor, VEGF-C, is a ligand for the FIt4 (VEGFR-3) and KDR (VEGFR-2) receptor tyrosine kinases. EMBO J. 15, 290-298.

Ladoux, A., and Frelin, C. (1993) Hypoxia is a strong inducer of vascular endothelial growth factor mRNA expression in the heart. Biochem. Biophys. Res. Commun. 195, 1005-1010.

Lagercrantz, J., Farnebo, F., Larsson, C., Tvrdik, T., Weber, G., and Piehl, F. (1998) A comparative study of the expression patterns for VEGF, VEGFB/VRF and VEGF-C in the developing and adult mouse. Biochim. Biophys. Acta 1398, 157-163.

Leung, D.W., Cachianes, G., Kuang, W.J., Goeddel, D.V., and Ferrara, N. (1989) Vascular endothelial growth factor is a secreted angiogenic mitogen. Science 246, 1306-1309.

Machein, M.R., Kullmer, J., Fiebich, B.L., Plate, K.H., and Warnke, P.C. (1999) Vascular endothelial growth factor expression, vascular volume, and capillary permeability in human brain tumors. Neurosurgery 44, 732-740.

Maglione, D., Guerriero, V., Viglietto, G., Delli-Bovi, P., and Persico, M.G. (1991) Isolation of a human placenta cDNA coding for a protein related to the vascular permeability factor. Proc. Natl. Acad. Sci. U.S.A. 88, 9267-9271.

Maglione, D., Guerriero, V., Viglietto, G., Ferraro, M.G., Aprelikova, O., Alitalo, K., Del Vecchio, S., Lei, K.J., Chou, J.Y., and Persico, M.G. (1993) Two alternative mRNAs coding for the angiogenic factor, placenta growth factor (PIGF), are transcribed from a single gene of chromosome 14. Oncogene 8, 925-931.

Marsault, R., Vigne, P., Breittmayer, J.P., and Frelin, C. (1990) Astrocytes are target cells for endothelins and sarafotoxin. J. Neurochem. 54, 2142-2144.

Nauck, M., Karakiulakis, G., Perruchoud, A.P., Papakonstantinou, E., and Roth, M. (1998) Corticosteroids inhibit the expression of the vascular endothelial growth factor gene in human vascular smooth muscle cells. Eur. J. Pharmacol. 341, 309-315.

Nomura, M., Yamagishi, S., Harada, S., Yamashima, T., Yamashita, J., and Yamamoto, H. (1998) Placenta growth factor (PIGF) mRNA expression in brain tumors. J. Neurooncol. 40, 123-130. 
Olofsson, B., Pajusola, K., Kaipainen, A., von Euler, G., Joukov, V., Saksela, O., Orpana, A., Pettersson, R.F., Alitalo, K., and Eriksson, U. (1996a) Vascular endothelial growth factor $B$, a novel growth factor for endothelial cells. Proc. Natl. Acad. Sci. U.S.A. 93, 2576-2581.

Olofsson, B., Pajusola, K., von Euler, G., Chilov, D., Alitalo, K., and Eriksson, U. (1996b) Genomic organization of the mouse and human genes for vascular endothelial growth factor B (VEGF-B) and characterization of a second splice isoform. J. Biol. Chem. 271, 19310-19317.

Olofsson, B., Korpelainen, E., Pepper, M.S., Mandriota, S.J., Aase, K., Kumar, V., Gunji, Y., Jeltsch, M.M., Shibuya, M., Alitalo, K., and Eriksson, U. (1998) Vascular endothelial growth factor B (VEGF-B) binds to VEGF receptor-1 and regulates plasminogen activator activity in endothelial cells. Proc. Natl. Acad. Sci. U.S.A. 95, 11709-11714.

Phillips, H.S., Armanini, M., Stavrou, D., Ferrara, N., and Westphal, M. (1993) Intense focal expression of vascular endothelial growth factor mRNA in human intracranial neoplasms: Association with regions of necrosis. Int. J. Oncol. 2, 913-919.

Plate, K.H., Breier, G., Weich, H.A., and Risau, W. (1992) Vascular endothelial growth factor is a potential tumor angiogenesis factor in human gliomas in vivo. Nature 359, 845-848.

Raynal, F., Michot, B., and Bachellerie, J.P. (1984) Complete nucleotide sequence of mouse $18 \mathrm{~S}$ rRNA gene: Comparison with other available homologs. FEBS Lett. 167, 263-268.

Salven, P., Lymboussaki, A., Heikkila, P., Jaaskela-Saari, H., Enholm, B., Aase, K., von Euler, G., Eriksson, U., Alitalo, K., and Joensuu, H. (1998) Vascular endothelial growth factors VEGF-B and VEGF-C are expressed in human tumors. Am. J. Pathol 153, 103-108.

Schmidt, N.O., Westphal, M., Hagel, C., Ergun, S., Stavrou, D., Rosen, E.M., and Lamszus, K. (1999) Levels of vascular endothelial growth factor, hepatocyte growth factor/scatter factor and basic fibroblast growth factor in human gliomas and their relation to angiogenesis. Int. J. Cancer 84, 10-18.

Seetharam, L., Gotoh, N., Maru, Y., Neufeld, G., Yamaguchi, S., and Shibuya, M. (1995) A unique signal transduction from FLT tyrosine kinase, a receptor for vascular endothelial growth factor (VEGF). Oncogene 10, 135-147.

Shweiki, D., Itin, A., Soffer, D., and Keshet, E. (1992) Vascular endothelial growth factor induced by hypoxia may mediate hypoxia initiated angiogenesis. Nature 359, 843-845.

Silins, G., Grimmond, S., Egerton, M., and Hayward, N. (1997) Analysis of the promoter region of the human VEGF related factor gene. Biochem. Biophys. Res. Commun. 230, 413-418.

Terman, B.I., Dougher-Vermazen, M., Carrion, M.E., Dimitrov, D., Armellino, D.C., Gospodarowicz, D., and Böhlen, P. (1992) Identification of the KDR tyrosine kinase as a receptor for vascular endothelial growth factor. Biochem. Biophys. Res. Commun. 187, 1579-1586.

Vigne, P., Champigny, G., Marsault, R., Barbry, P., Frelin, C., and Lazdunski, M. (1989) A new type of amiloride sensitive cationic channel in endothelial cells of brain microvessels. J. Biol. Chem. 264, 7663-7668.

Weindel, K., Moringlane, J.R., Marmé, D., and Weich, H.A. (1994) Detection and quantification of vascular endothelial growth factor/vascular permeability factor in brain tumor tissue and cyst fluid: The key to angiogenesis? Neurosurgery 35, 439-449. 